\section{Mentoring and the .Role of the Principal}

\section{Michael Simpson}

$I^{n}$ $\mathrm{n}$ the current climate of schooling in Ontario for teachers, leaders in education are faced with numerous challenges. School reform is a constant; changes in curriculum, assessment and evaluation are on-going; accountability is a factor that districts, individual schools and teachers themselves face. Provincial testing of students coupled with the scrutinizing of teachers' professional development are only two sources of the pressures felt by those in the classroom today. In Ontario over the next five years, all teachers will have to complete a minimum of fourteen professional learning courses to maintain their license to teach; graduates from faculties of education will have to pass a qualifying test as of May, 2002; and a uniform performance appraisal process for all those teaching in the province is looming. (Capstick, 2001). Teachers, at best, are feeling that the government, the public and, at times, their own district school boards do not show enough regard for what they do with students on a daily basis. There are current and clear trends unfolding in our province: more teachers are retiring at an earlier age than in the past. In 1999, 9,817 teachers left the rolls of their pension plan. Of these 5,142 retired and 4,414 quit teaching, a figure that represents a 23 percent increase over the previous year. By December, 2005, another 46,000 are expected to leave the profession. (Clark, 2001) A teacher shortage in Ontario is imminent. Anxiety, frustration, and confusion abounds in our profession. Given these less than ideal conditions for teaching, what can be done to encourage and to retain those who have newly entered the profession? Let's begin with an assumption that may override much of what is outlined here; namely, that teaching in a secondary school setting is a daring and at times, a daunting act; that it is a decision, once committed to, does not pose an easy road to professional happiness. Those who choose to teach require a professional network of support.

The principal has been traditionally the one responsible for the introduction of new teachers to the school. Unfortunately, the weight of other traditions that suggest teachers be self-sufficient, independent and able to solve their own professional challenges has slowed the acceptance, and the range of new teacher induction support services. Once qualified, the thinking has gone, is it not an admission of weakness for a beginning teacher to seek outside help? Is it not a comment on a system or a school when a successful candidate is in apparent need of on-going assistance? The fallacy of such ideas is underlined when we consider another view: teachers are learners too and should always be considered as such. The nature of the schooling we design for our students - a diversity of learning opportunities to achieve excellence, an engagement and an enthusiasm for the kind of learning that promotes risk-taking and a connection to prior experiences should be considered meaningful and essential to the professional development of teachers as learners as well. Outside of the tradi- tional staff development days offered by schools and districts, some of which focus on decontextualized topics offered by external sources of expertise, there has been little more than an ad hoc approach to mentoring new teachers. Those just starting their careers do need to learn to work independently, to value their own instincts, to reflect on their practices and lay the foundations for assuming increasing roles of responsibility. The question that lies at the centre of the issue of mentoring or coaching new teachers, then, is how should one approach such a significant element of improving effective, progressive and excellent instruction in their school?

As the instructional leader, the school principal still must assume the role of facilitator: one who will provide opportunities to the teacher for collaborating with others to approach authentic problem solving, to discuss complex school and classroom issues and to build trust with those who are similarly struggling in our educational environment that is constantly in flux. The task for the principal is to design policies and practices that both attract and retain the quantity and quality of teachers and to provide sustained support for them, immediately and on-site. (Peske, Liu, Kauffman, and Kardos, 2001) Facing the vicissitudes of teaching and learning, exchanging and developing new ideas collegially are essential not just for the personal development of the new and the more experienced teacher, but are pivotal in the broader arena of bringing about real and sustained reform in schools. (Feiler, Heritage and Gallimore, 2000) Teachers, together, must continue to adapt to change and to continue to take new approaches to educational practices. Principals must ac- 
tively support a teacher new to their school by these actions:

select and assign experienced mentors who are committed and have a solid understanding of the role of providing guidance and support to new teachers. These teachers may be department chairs or other teachers interested in volunteering their expertise.

help shape an agenda for both parties that is sensitive to their concerns, their circumstances and their need for support as they work together.

talk with mentors and new teachers equally; offer your perspective on practices, but listen with empathy and respect their knowledge and abilities.

display a discernable eagerness to acknowledge and to help alleviate the problems that the mentor and the inductee have identified.

arrange schedules between mentoring teachers and their charges so that there is possibility for regular and shared activities. Having a new teacher watch an experienced one or having a mentor observe and provide feedback are critical elements to the success of improving student and teacher learning.

avoid downloading the most challenging classes to the new teacher. Provide equitable and reasonable teaching assignments.

make suggestions, provide feedback and praise the new teacher as an active participant in the mentoring process. Visit the classroom and talk frequently with the teacher about best practices.

The effective facilitator must display a strong sense of the productive meaningfulness to the practice of collaborative relationships: it is these relationships that form the basis of our shared labours in teaching. Most clearly, the principal needs to show a firm appreciation of the relationship between the collegiality of the mentors and new staff and the ultimate establishment of a new teacher's personal sense of adequacy and the worthwhile purpose of his or her endeavours. Striking that difficult balance of developing staff in ways that the principal knows are important and providing what the new teacher wants is the primary goal of a mentoring program. Indeed, the efficacy of mentoring is in providing not just information or procedural services to the fledgling teacher, but a series of challenges that will empower the teacher/ learner and intensify the personal and professional connection to their own pedagogical experiences. (Payne and Wolfson, 2000)

In addition to the approaches discussed previously, principals must perform other essential functions as an effective facilitator:

promote collaboration, collegial approaches and reflective discussion within the whole school.

show that you are committed not only to school improvement, but the enhancement of a professional community or spirit within the school by creating time and opportunities for collegial reflection

model those behaviours that show that schools and teachers can make a difference; establish a sense of shared purpose and urgency to schooling.

promote a sense of a community of learners in your school: shared work, shared interests and shared struggles instil an authentic spirit of trust and professional relationship that are keys to a school that does well.

distribute helpful professional literature and create opportunities for participatory learning for new staff at conferences, workshops, or discussion groups.
The principal must also recognize the importance of facilitating those links between the new teachers and other support services in the district be it federation or board personnel. Showing the way must include providing a delicate balance of information sharing and psychological support. For teachers to perform their duties well, they must have a solid understanding of how the outside system operates, so that they can focus on making significant personal progress inside their own school and their classrooms. As complex organizations, district school boards are just another level of awareness for beginning teachers to master. We initiate those new to the system via elaborate policies, procedures, regulations, and professional expectations. Principals should do whatever is necessary to heighten the new teachers' understanding of how to work within the system so as to free themselves to step outside of the structures and focus their energies on improving student learning and the schools in which they teach. (Lieberman and Grolnick, 1997)

New teacher orientation to the district's organization or to the teachers' federation, albeit extraneous to the daily tasks of the classroom, are nevertheless critical. The principals' role here is to provide the time and to promote consistently the new teacher's participation in such information sharing sessions. Professional development training on the effective completion of provincial report cards, conducting meaningful parent/teacher interviews or being introduced to the board's administrative personnel and their respective roles, for instance, must be considered by the principal as essential to the broader perspective of the new teacher's induction. Workshops by board support staff, special education 
services or in-services conducted the O.S.S.T.F. on classroom strategies are clearly significant support mechanisms for a new member on a teaching staff. The subtle power of encouraging the new teacher to participate in such activities can be just as motivating as what an educational leader models.

Successful schools that instruct their students in meaningful ways are dependent on a cadre of teachers who are intent on working in a culture of collaboration, innovation, reflection, and mutual support. As the need for new teachers intensifies and school districts compete for those who choose to engage in this community of learners and who wish to contribute toward education's capacity for thoughtful reform, the role of the collegial school leader is ever more central. By maintaining a clear sense of how teachers make whole school improvement truly work and the concomitant need to promote genuine and trusting relationships among educators both new and veterans in the profession - the principal will ensure the instructional well-being of the students in a school and just as significantly, will enhance the level of teachers' motivation, sense of purpose and professional happiness. It is educational con- siderations such as these that should shape the thinking of a principal intent on leading a school through these turbulent and uncertain times.

\section{References}

Capstick, L. (September 2001). "Let's Focus On What Makes Us Better Teachers". Professionally Speaking. Toronto: Ontario College of Teachers.

Clark, R. (January 2001). "Teacher Shortage In Ontario". OSSTF, 28,7 .

Feiler, R., Heritage, M. and Gallimore,. R. (April 2000). "Teachers Leading Teachers". Educational Leadership, 57,7:66-69.

Lieberman, A. and M. Grolnick. (1997). "Networks, Reform and the Progessional Development of Teachers". In Rethinking Educational Change With Heart and Mind, edited by A. Hargreaves. pp.192-215. Alexandria: ASCD.

Payne, D. and Wolfson, T. (October 2000). "Teacher Professional Development - The Principals' Critical Role". NASSP Bulletin, 84, 618: 13-21.

Peske, H. , E. Liu, S. Johnson, D. Kauffman, and S. Kardos (December 2001). "The Next Generation of Teachers: Changing Conceptions of a Career in Teaching". Phi Delta Kappan 83, 4: 304-311

\section{Implementing Leadership}

Continued from page 12

Sylwester, R. (1997). How emotions affect learning. In P. Robbins \& J. Scott (Eds.), Emotional Intelligence (pp. 1 -6). Alexandria, VA: Association for Supervision and Curriculum Development.

Tardif, M. (2001). Pre-service teacher training programs: Outcomes of recent reforms and new trends towards effective professional training. Prepared for the 2001 Pan-Canadian Education Research Agenda Symposium. Quebec City.

Thoreau, H.D. (1846). Walden. In N. Baym et al. (Eds.), The Norton Anthology of American Literature (pp. 889 - 909). New York: W.W. Norton.

United States Department of Education (1998). Achieving excellence in the Teaching profession. In Promising Practices: New Ways to Improve Teacher Quality.

United States Department of Education (1993-94). National Center for Education Statistics. Schools and Staffing Concerns.

Weisinger, H. (1998). Emotional Intelligence at Work: The Untapped Edge for Success. San Francisco: Jossey-Bass Publishers.
Hamilton Training Advisory Board Commission consultative sur la formation à Hamilton

Preparing today's workforce for tomorrow's workplace.

www.hwtb.on.ca info@,hwtb.on.ca

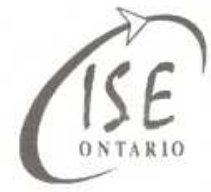

INTERNATIONAL STUDENT EXCHANGE - ONTARIO Programs For Ontario Students secondary \& elementary Reciprocal Exchanges during the school year: 3- and 2-month Reciprocal Exchanges during the summer: 1- month

Summer Credit Courses Abroad in Spain and Costa Rica

Special Program for Faculty of Ed Students

Internship Abroad for 4 to 6 weeks after exams

Summer Seminar in Europe for Ontario Teachers

PLEASE VISIT OUR WEB SITE www.iseontario.on.ca 